\title{
I am Therefore You Are: \\ An Existentialist Perspective on Wole Soyinka's Writings
}

\author{
Lawrence Ogbo Ugwuanyi* \\ DOI: http://dx.doi.org/10.4314/ujah.v12i2.3
}

\section{Abstract}

This essay sets out to account for the existential import of the writings of Wole Soyinka. It submits that the writings of Wole Soyinka define life as a void in search of meaning which man can only accomplish through the affirmation of the will to live, freedom and conquest. The work draws positions from a number of Soyinka's works especially those dedicated to the Ogun deity who, for Soyinka serves as a moral standard for mankind, to illustrate how the same quest for vitality and affirmation of the human essence runs through his works The work establishes the claim that Wole Soyinka's works define life in terms of quest for the autonomy of the individual. It locates Soyinka's existentialist conviction in the belief that only the human essence deserves unqualified allegiance for which every other item or value: culture, institution, constitution, agencies, government, etc, should be negotiated to its favour. The work then goes forward to establish how the contradictions inherent in the human reality and the desire to overcome these contradictions and authenticate the self result in such themes as freedom and justice through which we ascribe meaning to life. The work concludes by drawing an analogy between Wole Soyinka's existentialist convictions and those of Fredrick Nietzsche the German philosopher, whose ideas stand at the root of the existentialist tradition of philosophy. 


\section{Introduction}

In a debate in The Vanguard ${ }^{l}$, a notable Nigerian daily, a commentator once observed that Wole Soyinka is not a writer but a thinker. This important remark which came from a public voice on Soyinka, as against the academic flora where Soyinka is admittedly a celebrity, deserves a consideration for the intellectual world. This is because if Soyinka should lose his identity as a writer, anyone who is bold enough to deny him this identity should be rigorous enough to provide him with another. This essay sets out to support this claim and to establish the fact that the merit of Soyinka as an intellectual lies fundamentally on the quality of his position as a thinker as a result of which his essays are an elaboration of a deep insight into the human phenomenon. The essay sets out to establish claims that validate this position by articulating the relevant views of Soyinka implied in this claim. To do this, the work examines Soyinka's works from an existentialist perspective.

The work begins by articulating the idea of existentialism, then looks at the idea of being human or what the paper calls the human essence in Soyinka to establish that although Soyinka appears not have an articulate and coordinate idea of what being human should be, his concern with the evolution of ideals that should define the human phenomenon is what leads him to document views and ideas that qualify him as an existentialist thinker. Thereafter, the work looks at how this quest for the authentic affirmation of the individual stands 'as an enduring cultural force in Soyinka's works and concludes by providing a comparison between Soyinka and Nietzsche, the well known German philosopher whose ideas stand at the root of the existentialist tradition of contemporary philosophy. 


\section{The Existentialist Creed}

Existentialism is a philosophical school of thought that holds that there is a quality of living that defines life properly and therefore mirrors the call of being human. This quality of living is marked by freedom and the proper exercise of the will in a chosen direction and for this reason is considered worthier and more authentic. Macquarrie defines authentic existence as:

That mode of relation to the other that promotes existence in the full sense; that is to say, it lets the human stand out as human, in freedom and responsibility. ${ }^{2}$

Authentic existence is a prominent feature of existentialist philosophy founded by the Danish philosopher Soren Kiekergaard popularly known as the father of this trend of thought. Beginning with Kiekergaard to Jean Paul Sartre, Gabriel Marcel, and others, existentialist philosophy seek to place man on proper rational ground to evaluate his quality of life and manner of living. Indeed, it was Jean Paul Sartre who articulated a definition of existentialism properly, with the view that "existence precedes essence" ${ }^{3}$. What Sartre implies by this view is that human existence becomes what it is by its manner of living. To the extent that this mode of living is close to the basic ideals desired by man such as freedom and responsibility, to that extent it is qualified as authentic.

In the light of this, authentic existence can be conceived as that mode of living that is real and true to life while the inauthentic existence is the one that is false and untrue to life. Since the end of the Second World War this current of philosophical thought whose aim is to interrogate and promote the quality of human existence has dominated Europe and the western world. 
Existentialist philosophers usually discuss the general features of human existence. Their concern usually includes such issues as the human reality, human freedom, anxiety, and responsibility, exercise of the will and the actuation of the human potential. Through an analysis of these themes, they define how the human being should define his existence and respond to the challenge of human existence. It is therefore the common opinion of existentialist philosophers, that human existence is for activity and recreation; that man must choose and choose the principles on which he chooses; that the quality of his choice determines the quality of his humanity; that he should be allowed to define life in his chosen direction.

Existentialist philosophers also make a distinction between the quality of human life and that of non-human life and accord priority to human life. It is their view that existence as a concept should only be applied just to the being that is human: for man alone, in their thinking exists. Hence the German phenomenologist and existentialist, Martin Heidegger holds that "Without man there is no world..."to be" cannot have any other meaning than to-be for man." Heidegger's position which is a reflection of the entire existentialist creed is that man is unique in his mode of being by his quality of rationality for only man has the duty to negotiate life and to make himself through a proper exercise of his will. But this project of being human is to a co-operative project in which every being is involved in the institution of man.

Existentialist philosophers reflect on what it means to be human and how to realize the human essence. For this reason, their concern includes such themes as freedom, justice, courage, power, etc. But the manner of this concern is also part of what defines them. In relation to such broad concepts as justice and power, the existentialist concern is on 
has these virtues go to define and authenticate the human quest for meaning and value. The concern with justice or power is not the political or economic implications for the exercise of power, but how, by the exercise of power, the human essence and meaning is affirmed and realized.

Existentialist philosophers often document their positions through a prolonged engagement with the human drama. Thus, it is no doubt that many existentialist thinkers have been writers and thinkers whose works are adjudged to be of high literary quality. Thus great exponents of existentialism such Jean Paul Sartre and Albert Camus have substantially been writers whose have attempted to dramatize life in their works, and whose effort enabled them to achieve a peculiar idea of the human drama through this effort.

It is in the same category of writers that we locate the Nigerian Nobel Prize winner for literature Wole Soyinka. Soyinka's lifelong engagement with the human drama through writing has led him successfully to a level where he can justifiably be categorized as an existentialist thinker. To demonstrate this claim is the focus of this paper and I begin by discussing Soyinka's humanism which is route to understanding the basis of his existentialist convictions.

\section{Soyinka's Humanism}

Perhaps no work articulates Wole Soyinka's humanist conviction than an interview he granted to Humanist International in 1997. In this important interview Soyinka had said;

Humanism for me represents taking the human entity as the centre of world perception of social organization and indeed of ethics, deciding in other words what is primarily of the greatest value for humans as opposed to some remote extraterrestrial or ideological authority. And so 
from that point of view, I consider myself a humanist"

Soyinka's humanist creed can be likened to that of the ancient Greek Philosopher Protagoras. For Protagoras, "man is the measure of all things, the things that are, that they are and the things that are not that are not" ${ }^{36}$.For Soyinka, the centralization and enthronement of the supremacy of human concerns constitutes therefore, a fundamental item to measure the quality of the human world; a yardstick to measure(1)The primacy of human dignity (ii)The constitution of institutions that defend and promote human dignity, where rights are accorded human beings and (iii)A world of greater freedom, equality and justice. Hence, Soyinka believes that institutions and constitutions; agencies and governments, creeds and religions must serve the cause of man and only on this ground can their existence be justifiable.

Soyinka's belief in human essence is one in which he does not recommend any institution to formulate principles or theories to defend its cause. It is one which allows man to invent himself and defend himself; one in which the ethics, epistemology, anthropology and above all metaphysics emanating from man should inform, educate, organize and legislate the human society. Hence, Soyinka maintains an aversion for religious authority and professes secularism. In the interview with Humanist International cited earlier, Soyinka had explained his secularist conviction with the position that: those who "believe passionately in their deity should reserve to that deity the authority to extract vengeance"(FE). As he puts it further;

They shouldn't make themselves the instrument of imagined wrongs. That applies to any religion, it applies to the insanity between the Hindus and Muslins in India, to the Jewish 
extremists in Israel. It applies to any kind of religion in the world (FE).

This message of secular humanism runs through Soyinka's works in several themes, titles and forms. In a public lecture delivered at the University of Ibadan, in 1991, titled "The Credo of Being and Nothingness", Soyinka had taken on this theme in a more elaborate manner and commended African religions as a worthy variant to the fanaticism of many imperial world religions. Soyinka notes that there are religions which have man at the centre "such as on this continent, that can boast of never having launched a war, any form of jihad or crusade, for the furtherance of their beliefs" . On this note, he reminds the foreign imperial religions in Africa, notably Christianity and Islam that they are in no way creating a religious space anew in Africa, but occupying a space already created by African Traditional Religion. Incidentally, their ethics of dominance and conquest does not tally with the original values of African traditional religion. Hence he recommends that they learn from this religion.

The import of Soyinka's critique of religion is that the quest for the authentication of the human essence does not tolerate fanaticism which in essence is piety devoid of reason. Irrational piety cannot promote reason and tolerance which are the routes to the affirmation of the human essence and dignity. Hence Soyinka recommends the Yoruba religion as a worthier alternative, in terms of ideals, for this religion, in the words of Soyinka is "one of the most humanist types of religion you will encounter anywhere in the world"(FE). Soyinka provides an elaborate thesis in this regard; According to him:

The Yoruba philosophy drastically reduces the absolute authority of deity over the lives of 
human beings and therefore the dependency of human beings on the interpreters of the extraterrestrial authority (FE)

Soyinka's idea of man then is one embedded in a belief in egalitarianism, secularism and equality. This belief recommends a cautious management of human differences in a way that promotes human welfare without undermining human dignity since, for Soyinka there must be a time in the evolution of the human mind "when the perception of differences in humanity is reduced to an absolute minimum". In another lecture titled: "I Am Right You Are Dead", Soyinka identifies himself as a secular ideologue for whom human differences is reduced to an absolute minimum". This secularism is one which had grown from agnosticism to outright atheism (CF, p.113). But secularism as an ideology needs a root or basis. To profess an aversion for religion and faith in man as an end, demands that we articulate an idea of man. The question then is: what is Soyinka's idea of man? Is there an idea of man we anticipate from Soyinka in his project of humanism? To address this question let us attempt to articulate a theory of man that could be said to be implied by Soyinka.

\section{Soyinka's Humanism as a Form of Existentialism}

If we attempt to articulate the roots or foundations of man in Soyinka's humanism, we meet a large and deep disturbing hole. Soyinka is more prepared to live the human project at the mercy of the human than invent any root or basis for him. For Soyinka man is a bundle of contradictions and mankind an unending cycle of folly and stupidity, hence, the human project demands visionary attempts to combat the forces that pontificate and promote these contradictions. What he 
aggressively purses in his works and ideas are those vices that prevent the emergence of the human phenomenon.

For Soyinka "I am" is defined in terms of the sacrifice I must be allowed to do for you to become more human. You must give me the right to be for you. This right of being is defined in terms of certain vision I am privileged to have for which I have the authority to define being and living for you. I am, is the will to be, emanating from the will to action, itself emanating from reason. In the light of this belief, the meaning of life comes from experience gained in action or involvement, not in the theoretical talk in the classroom ${ }^{10}$ but in active life rooted in an abiding defense of human values.

While therefore leaving the human project open for self invention, Soyinka believes that a certain privilege of wisdom awards man the right to define truth, and to define existence for others. Thus while be does not wish that man submits his essence to social forces and authority, he entirely subscribes to a self-invented authority deriving from wisdom. We are then confronted with a profound theory of egoism; one that authorizes truth by oneself and insists that others should be ready to accept this self-invented authority.

It will then be right to qualify Soyinka's humanism as an anti-authoritarian position which lacks an authoritarian anchor, expect perhaps Soyinka himself - and for this hold that Soyinka is anti-hegemony in all its shades and forms; and that this defines his idea of constituted and instituted forms or organs for defining and dictating and directing the human society. Not even the gods or the divine is qualified for reverence in this life-long experiment in self-invention and recreation. Hence, in elaboration of this conviction, Soyinka contemptuously writes of the divine: Without the knowing of divinity by man, can Deity survive? Orisa reveals Destiny as Self-Destination.(CBN,p.35) 
Although Soyinka presents the above position as his own attempt at what he calls "eliciting a sets of seven precepts from the teachings of Orisa" (CBN,.33), to which ,the above belong, it is extremely difficult to accredit this view of Orisa or any divinity as Soyinka does, for any deity that holds that almost nullifies the superhuman quality of the deity. If the survival or existence of the deity depends on our knowledge of the deity, will it still have any basis to claim divinity? It appears therefore rather more convenient to argue that Soyinka is merely demonstrating his anti-authoritarian as well anti-divine and anti-superhuman convictions by the above position.

Paradoxically, Soyinka needs the moral authority of the divine to validate his claim to a higher moral conviction and deeper vision of the human phenomenon. The gods or the divine thus, for this reason may then serve as a moral standard for mankind in the event that the same standard they promote is what man needs to organize and sustain his status as a humankind. They may not and do not deserve the ritual of worship and reverence, in Soyinka's anthropomorphic conviction since they are united by the same ideal that even perhaps they themselves need to hold and re-affirm on and on, to retain and sustains their status.

It is then curious, yet, now understandable why Soyinka shuttles or oscillates between naïve religious conviction and outright atheism. While he needs the idea, theory or reality or awe of the gods to validate his pronounced egoism, the same gods do not deserve intimate worship or communion which is the hallmark of religious conviction. Unlike the Nigerian musical icon, Afro-beat King Fela Anikulapo Kuti, his cousin, another unbending egoist whose own quest for the reinstatement of the moral and intellectual autonomy of the individual led him back to African traditional Religion, for which he erected and worshipped at a shrine to exemplify his 
conviction in African Traditional Religion, Soyinka would have none of these. He is not ready to profess any deep faith in any religion by way of worship, even for Ogun, the Yoruba god that he holds in high esteem.

Twice however, it is on the record that Soyinka attempted a form of worship to a deity. The first was when his attempt to direct his play Death and the King's Horsemen in Chicago was met with scores of misfortune as the personnel he rented for the event sustained one injury after another leading what would mean an outright failure of the project. As the narration has it: Soyinka slaughtered a cockerel and "everything began to go well". ${ }^{11}$ The second instance was before the departure of the Nigerian delegates to Sweden for his Nobel award in Literature in 1986. Soyinka,the story goes again ordered his sister to slaughter a ram before their departure from Nigeria; and this she faithfully $\operatorname{did}(\mathrm{ZJ})$. These two instances demonstrate his occasional intervention in the domain of the divine and his attempt to be involved in the humble world of the divine worship. But this nowhere makes Soyinka religious in the deep sense of the term. Indeed Soyinka has never accepted the authority of the divine beyond this point. Thus while we may read beautiful imageries fashioned after biblical imageries or the salivific character of Jesus Christ in the poems of Soyinka or even volumes of literary works mirroring the morality of Ogun the Yoruba deity, these do not demonstrate any form of religious conviction as these are not done to elicit or provoke a sense of worship or reverence for the divine but serve as mere rational convictions on the values and ideals that these superhuman agents represent.

As to his anti-institution, Soyinka's stand on this is well known on this. All forms of organs and institutions that attempt to "panel-beat" or remake man according to a set of values must be interrogated or suspected and their acceptance 
must be based on how and whether they promote human freedom and choice. Not even culture which stands as total symbol of this project is sparred of this rational stance. Thus even when culture plays the role of the mental prism or spectacle that opens the gate to life and meanings it cannot be tolerated in Soyinka's anti-constitutional and antiinstitutional philosophy. Culture too, must be supervised by the human rational lens or prism.

In a lecture entitled "Culture, Memory and Developmemnt" 12 Soyinka had held that culture cannot be violent to man, in any form, and should not be one that leads to "forced population shifts or annihilation of communities"(CMD), for it is "crime against culture when a people or person is yanked out of its organic, productive milieu and dumped in a contrived, alien environment even under the most liberal dispensation"(CMD) in obedience to culture or cultural positions.

Thus Soyinka is clearly liberal and -institutional in his worldview that it may be considerably difficult to classify his works under any singular ideology. This again attests to his liberal outlook which prefers a critical and suspicious outlook on life than a settled one that annihilates creative ingenuity. His essays reveal the works of a thinker whose personal belief recommend him to insist on saying the world as he sees it and not as how others see it, as a result of which his scholarship ,by way of detailed and prolonged study or rigorous analysis of better mind before him are scanty. While he prefers to play the role of an "interpreter", "interventionist" 14 and a pronounced participant in the Nigerian nay African drama from where he identifies with the human drama in its political dimension, this does not and should not becloud the fact that Soyinka inverts and subverts ideals, details and values, to any direction that his mind points to. Even when these ideas pose conflicts to the public 
opinion or unpopular for adoption, his claim to a higher vision of the human society defines his focus and direction, for which he holds unto them. Hence he has been he has been adequately been described as an "obscure" and "privatist" intellectual.

Several examples demonstrate Soyinka's penchant for subverting ideals and going against conventional norms and values. As a youth in Nigeria he is known to have held a radio station in the former mid western Nigeria to prevent a broadcast of what he perceived to be a deceptive political agenda designed to mis-inform and mislead a political public. As a college student, at the University of Ibadan, Soyinka was one of the foundation members of Pyrates Confratenity: a "visionary" ${ }^{16}$ organization, which set out to provide a nonconventional route to justice with the ambition to curb the success of colonial project on the African mind by promoting the egalitarianism of African society.

During the Nigerian crises of 1967-1970, Soyinka is known to have singularly met with the Biafran leader, the then Col. Odumegwu Ojukwu with the aim of initiating an alternative formula for peace devoid of war. Similarly, during the reign of the Nigerian dictator late General Sani Abacha, Soyinka is known to have seen to the birth of a gorilla radio station that eventually settled in the United States of America to provide an air of propaganda against the regime which itself was built and nurtured on a project of deceit, lies and propaganda.

In Soyinka's life, works and ideas we, therefore witness a voice or life from without, a life without roots, roots interpreted to mean authority in human terms or basis. The roots or foundation of Soyinka is simply a certain claim or privilege to a social vision derived from "history and the material world" (CF, p.111) from where he derives and as well validates his claims to knowledge, wisdom and higher 
ideals. It is perhaps for this reason that Soyinka has been described as one who lacks faith in the collective will of the society and a "fiercely individualistic" ${ }^{\text {"17 }}$ character. Thus his "ardent humanism"(UBS) notwithstanding, Soyinka does not admit the idea of leaving or laying the human destiny at the village square of collective will since it will lead to wars and deaths and lead to the extinction of the human species. To do so would be to deny that human community a salvation or remedy, from any of their own who is considerably privileged with a certain gift of intellectual and moral vision. This gift of vision is what Wole Soyinka claims for himself in contemporary Nigerian, nay African world and attempts to substantiate and validate in his ideas and writings.

It is important to note that this vision of salvation as a privileged gift which can only come from among someone in the human community runs through Soyinka's works in several themes and titles. He creates on and on a messianic personality out of several characters in his artistic works. In his work, The Strong Breed ${ }^{18}$ Eman and Olunde are ready to lay down their lives for the continuity of their race. In a section of his collection of poems Idanre titled "Lone Figure", Soyinka is at "sympathy for the individual whose ideals raise him above the society he wants to save, but to which he falls a victim" (PWS, p.28). Soyinka goes further to present the irony of exceptional figures like Jesus Christ who were not seen for what they are while alive "only to be revered after his death" (PWS,p.28). This feeling is what is expressed much more eloquently in the "Dreamer", which is also a part of the collection, and which celebrates individuals with prophetic insight who foresees the future, what it is leading to, and how to address the challenge of the future.

But while Soyinka advocates for an exemplary life, his moral standard is not one that should be recommended for a larger class of the society. His disposition to obvert, subvert 
and oppose social standards are legendary enough to merit this claim, and one can only imagine what it would mean if Soyinka 's intellectual and moral audience were to adopt the same formula to subvert social ideals in favour of their personal ideals. Surely this would lead to a cult of personality and unending world of relativism. It is then right to state of Soyinka as Nduka Otiono does that Soyinka is "an unpredictable human being whose maverick nature has seen him behaving like an apostle of oddities"19 and that this quality stands against him as a moral and social standard. For instance it is known that Soyinka, apart from being a literary and intellectual giant of considerable relevance, is also a hunter, who once "spent a Christmas with animals in the bush"(KGS;ibid) and contrary to any social ideal anywhere in the world, had presented a machete to a friend as wedding gift (KGS;ibid) These actions while they may be labeled as an innovation in social and moral norms also bespeaks of Soyinka as one who is constantly in search of social and moral values and ideals almost throughout his life. His aversion for modern technology as revealed in his earlier poems also strengthened this claim. Thus, while he accepts modernism, and the robust quality of life it promises, Soyinka has a standing suspicion against anything unnatural, insisting that only the creative will of individual should define and determine ideals and values and that it is in this ability or rather attempt to create new realities that being human should find its meaning. Impressively however it is this effort at innovation of ideals about the human phenomenon which qualify him as a visionary and a myth maker.

Indeed the relevance of Wole Soyinka as a modern African intellectual may just be in this than in anything else; for if an intellectual should be a question mark that interrogates social ideals as a way of raising that urgent question of the examined life through which a society 
articulates and defines its concerns then one can be right to argue that Wole Soyinka was precisely one, both in thought and in action. It is also this character that stands him as an African equivalent of Fredrick Nietzsche, the German philosopher whose ideas are a rebellious project against the social ideals of his time. My attempt to establish a close similarly between Soyinka and Nietzsche, will form the next part of this essay. They are in two phases. The first aspect which follow is entitled "Between Soyinka and Nietzcshe", while the second which concludes the essay is entitled "Soyinka's Tigerism and Nietzsche (Overman) Superman"

\section{Between Soyinka and Nietzsche}

A close similarity can be observed between the works and ideas of Wole Soyinka and those of Fredrick Nietzsche that it can conveniently be held that Soyinka is an African version or equivalent of Nietzsche. In the first place the two thinkers define life and meaning in terms of the will to action. Similarly, the two thinkers believe that the ontological pessimism that defines life should be subverted through sheer force of the will. The will in question is not one that leads to a religious or supernatural ethics but a natural belief that man can as well invent a meaning for life. Thus while a certain kind of ontological pessimism runs through Soyinka's works for which birth and death are portrayed as the same route to nothingness, there is the persisting belief in him that the individual will can surmount the sickening pessimism that defines life. The route to this then lies in the will to action.

This is in close resemblance to Fredrick Nietzsche, for whom man should live dangerously by rebelling against all ethics or cultures that limit the force of the will. To do this, man must discourage a solitary life of quietude, meekness or kindness. For Nietzsche, the challenge of being human is to achieve a spontaneous affirmation of life through an assertion 
of an individual that is commensurate with "quantum of power" ${ }^{\mathrm{\prime} 0}$ a man possesses.

Because of their belief in the moral and rational autonomy of the individual and their emphasis on the assertion of this will over and above popular or social will, Soyinka and Nietzsche are prepared to admit a situation where man constantly rebels against social norms and values and subvert the values that define a society. In his theory of superman, Nietzsche, holds that morality must "suit each rank of man"21 (PHP, 393) and for this reason, universal or common morality should be disregarded because they obstruct the will of the individual. For this reason, Nietzsche finds it necessary to repudiate, if not condemn Christian morality. For Nietzsche, Christian morality represents an attempt by the weak to pull down the strong. Hence he could not fathom the idea of the morality of very poor people who lived closely with one man called Jesus Christ; whose clearest credential was that he gave a contradictory thesis that renunciation of this world is the route to heaven, defining the future of the entire bulk of the human race that would come after him. For Nietzsche, this was the worst moral contradiction that should have ever been tolerated for the poor cannot institute a morality where power should have its say or way. For Nietzsche, Christian morality is the "morality of paltry people" (PHP, p.391)). Although Nietzsche had some regards for Christianity in its ability to promote the cause of the weak and the suffering, his main grouse is the desire to subject everyone to this morality which literarily encourages everybody to become same and erases completely the need for each person to realize himself according to his natural endowments. The position of Nietzcshe as Robert C. Solomon puts it is that;

...all over behaviour is to a certain extent compelled...by one's nature...thus a strong 
person cannot but be strong, and a weak person cannot but be weak, and in particular the actions they perform are thus "compelled"by their natures" 21.

For Nietzsche, we should just be who we are, and any moral evaluation of our action should be built or anchored on our natures our abilities, our inclinations, our tendencies, our desires, etc, especially in its individual variant.

Because of the striking similarities between Soyinka and Nietzsche we then witness two similar dispositions to their societies; while Nietzsche rebels against the Christian Europe of his time for her new morality that, for him led to "the deterioration of European race"(PHP) Soyinka is a rebel against the African society in both of traditional model and its modern form. While he insists on promoting the values of egalitarianism of traditional Africa and seeks to re-instate the values of egalitarianism, he does not accept this as a model in its entirety. Indeed it is only the values of justice and fairness which these values promote that form the driving force for this belief.His strong elitist disposition for which he speaks only to a class of the society, by his pattern of writing, stands as a clear contradiction to his belief in thinking for every social group. Soyinka is easily the most obscure writer in Africa who appears not be to be disposed to think for everybody.

Another striking resemblance between Soyinka and Nietzsche is their choice of mentors that inform their mental vision. For Soyinka the Yoruba deity Ogun is the moral standard for mankind-while for Nietzsche Appolo serves this cause. For Nietzsche Dionysius the Greek god symbolized what life should mean and be. Dionysius provided the basis for living a life which "defies all limitations"(PHP,p.387) and for this reason provided the basis for man's expression of his full potential. For Nietzsche, then Dionysus induces quasi- 
mental state of "oneness",22 which defies being in its ordinary form and promotes a quest for a higher metaphysical ideal. But although Nietzsche recognizes the creative and even recreative potential of Dionysius, he complements this belief with an equal stronger belief in Apollo the god of order, form and restrain or reason. What Nietzsche believes is that the vitality which Dionysius represents should be admired and adopted to express a rational ideal to its utmost, rational ideal in this instance is not that which is defined by any human being or institution, but the individual or the liver. Life can only be one defined by the individual.

In a similar vein, Soyinka's mentor is Ogun the Yoruba god of creativity. Ogun features in several works of Soyinka. He features in his plays: A Dance of the Forest ${ }^{23}$, and The Road ${ }^{24}$, his novel The Interpreters ${ }^{25}$ and his poem Idanre $^{26}$. "For Soyinka, Ogun is a moral standard. He is "the creative and yet destructive" god ${ }^{45}$.Indeed in Indanre, Ogun defines the theme, forms, vision and focus of the poems. For Soyinka, the creative character of Ogun is one that should be emulated by any human entity. Ogun symbolizes man's quest for life and meaning and for this reasons man's attempt to achieve a meaning for a life that has none, should be based on the qualities of Ogun.

Ogun is a god of seven parts, multi-dimensional in value. He is "god of iron and metallurgy, explorer, Artisan, Hunter, God of war, Guardian of the Road, the creative Essence. His season, is harvest and the rains" (PWS, p. 44). Ogun is "unpredictable, contradictory and violent" (PWS, p.44) Ogun, Soyinka's mentor "kills the child with iron with which it plays", and though he has water, bathes in blood"(PWS,p.44). Ogun thus represents that uncertainty and unpredictability that defines life through which man becomes almost as strange as life itself, refusing every inch, time and again, to allow life to estrange man, by presenting, anyone 
possibility that conquers and dominates the human imagination as the theme of life. In existentialist terms, Ogun stands as that possibility which defines what it mean to live, by defying monotony. Existence could only be defined by remaining open to human possibilities.

It is interesting that Soyinka's mentor would not be Orunminla, the Yoruba god of wisdom. Orunmila is the Yoruba god of "order, wisdom and authority"(PWS,p.6), yet Soyinka would not adopt him as a mentor, because order might lead to a formal process that institutionalizes reason. Order would only be, as defined by some authority, and inevitably lead to a defined form of life. Through order and some reverences to a superior authority, we can anticipate a construction of life for others and we are back to a situation witnessed when man is faced with a life that has been defined or made by other, and which in essence, denies the human possibility of inventing oneself through what Nietzsche, before Soyinka had long called re-evaluation of values. All these are quite antithetical to Soyinka, whose existentialist perspective is that everyman must be a voyage in the boat of life, and that the independence of choice and will stands at the heart of being human.

We can then see a strong striking similarity between Soyinka and Nietzsche. For Nietzsche life has more to do with living than knowing. Contemplation, quietude, reflection, and rational institution of truth are clearly at variance with the values that should define life. Man should live dangerously and dominate life with a higher will defined as will-to-power. For Nietzsche, the real challenge is to create ourselves and invent new values for, in real life, "it is only a matter of strong and weak wills" 27 . But self-making in this instance might not translate to social Darwinism and elimination of opponents or opposites or even the weaker. It translates to acts of the will that are both magnanimous and 
positively recreating. Nietzsche's vision is about a positive affirmation of life in a manner that creates and promotes new values but not religious values (such as faith) because this puts a dead end to reason and to a positive exploration of life. Hence Nietzsche articulates his philosophy through an important character Zarathustra, who rebels against faith and the contemplative life, and seeks instead, to install a world of the over-man or superman.

After ten years of solitude, Prophet Zarathustra returns to civilization, breaks the bondage that defines his life of solitude. He experiences a vision of life beyond and advocates a life that revolts against the existing slavish value of his generation. He advocates for "a higher type of beings capable of existing beyond nihilism resentment and the reactive values of slavish nature" 28 Zarathustra asserts:

Before God! But now this god has died! You higher men, this god was your danger only since he has lain in his grave have you again been resurrected. Only now does the great noon-tide come, only now does the Higher Man become lord and master... (FN,p.119)

He concludes with a great tone of authority and finality:

Very well! Come on you Higher Men! Only now does the mountain of mankind's future labour. God has died: now we desire -that the Superman shall live (FN,p.119) 
V

\section{Soyinka's "Tigerism" as a Version of Nietzsche's Superman: Concluding Observations}

Our attempt to establish a relationship or a worthy comparison between Soyinka's vitalism and Nietzsche's ethics of superman clearly proves that Soyinka and Nietzsche derive their inspiration from one source and their vision is informed by a quest for a higher human ideal which will serve as a testament of hope in man's' ability to create or redesign himself. It is in this instance that Soyinka is an African variant of Nietzsche, who should have read Nietzsche, extensively. Soyinka needed an intellectual ancestor to endorse his rebellious philosophy against just anything, but the human spirit or the human entity and Nietzsche was in reality available to provide this function.

At the beginning of the decolonization era, African intellectuals volunteered to provide an African variant of ideology to western ideology as the formula to mental decolonization: Leopold Sedar Senghor, poet and Pioneer president of Senegal proposed the ideology of negritude .Negritude in essence meant, a celebration of black colour and an attempt to convert the colour difference into a principle or basis for the re-affirmation of black humanity. In a contemptuous reaction to the ideology of negritude, Soyinka proposed a variant: the ideology of tigritude. For Soyinka, "a tiger does not boast of its tigritude, it acts it" 28 . This position which confirms Soyinka's belief in the will as the defining measure of reason stands as a worthy summary of Soyinka's idea of the individual, the I and the human. It confirms in very strong terms that the tension between the thought and action or the ideal and the real is not an enduring controversy in Soyinka's existentialist outlook. For Soyinka, we can only have validated our ethical conviction by the extent to which it has led us to, and sustained our action. 
Only the view with as much moral force and momentum, as can sustain our action, that is worth holding. Hence, in his important prison notes The Man Died Soyinka submits that: "the man dies in all who remain silent in the face of tyranny" 29 . There is no doubt that Soyinka whose life of political and moral activism is as much deep and detailed as his writings and intellectual resource is a strong testimony to the nobility of this belief, for Soyinka's life could simply be described as a document of political struggle to defend and preserve the human essence.

It is in this effort to articulate a strange life from an African setting that has promoted what is generally perceived as a western theory of the human -the I that the merit of our attempt to discuss Soyinka's existentialism lies. The search for the basis for life and meaning, the quest for authenticity should ordinarily have been left to the western intellectual tradition but Soyinka has been able to portray the problem of the African self with the thesis that the very assumptions on which the African expresses his belief in the human phenomenon for which he holds the creed that "I is in the We and $\mathrm{We}$ is in the I" ${ }^{30}$, deserves to be questioned to its roots as an urgent measure to interrogate and justify such a belief. His belief is that at no point should social belief and convictions assimilate the human person that fashions this belief .Hence, not even the colonial experience, or the post-colonial alternative or such traditions of thinking such as negritude should foreclose the personal encounter with life and meaning, through which we can validate our claim to existence. Once this is done, man comes to a dead end, culturally and otherwise, and with it, the vitality that defines the human possibility is also closed. This in essence is the substance that runs through a vast member of Soyinka's works and essays. His personal encounter with life informs his critique, study or satire of the social or institutional 
mechanism which come as devices and mechanisms that regulate life, for in all instance they can only be to the extent that I am. This in essence is the import of Soyinka's writings from an existentialist perspective.

\section{Notes and References}

1. Details of this debate can be read in the May 2000 editions of The Vanguard, a prominent Nigerian daily. The debate itself is a series of essays provoked by an article on the Nigerian poet Odia Ofeimun who is known to share some intellectual convictions with Wole Soyinka and whom one of the debaters argued was nothing short of aspiring to be just what Soyinka is -a thinker and not a writer. In a telephone chat with this author on Dec.19, 2007 on this debate, the poet Odia Ofeimum further elaborated on that debate arguing that the Soyinka that is a thinker is also the writer because he had managed to turn his thinking into a form of writing.

2. Macquarrie, J 1973, Existentialism (London; pengium Books),p.14

3. See Lacey, A.R.A, 1976, A Dictionary of Philosophy (London: Routeledge and Kegan Paul), p.64.

4. Luipjen, W.A. 1956, Existential Phenomenology (Louvain), p.29.

5. For details see Free Enquiry, a publication of Humanist International, Fall 1997 edition, p.48.Henceforth cited ad FE. 6.This is the position accredited to Protagoras the Greek philosopher who lived between 480 and 410 B.C as taken form Mann,J.A and kreyche, G.F, Reflections on Man Readings in Philosophical Psychology from Classical Philosophy to Existentialism(New York: Harcourt Brace and World.Inc,p.7 
7. Wole Soyinka,1991,The Credo of being and Nothingness(Ibadan: Spectrum),p.17.henceforth cited as CBN.

8. Wole Soyinka, 2004, The Climate of Fear: The Reith Lectures 2004(Ibadan: Bookcraft)p.109.henceforth cited as $\mathrm{CF}$

9. The Lecture is part of $\mathrm{CF}$

10. Tanure Ojiade, 1994,The Poetry of Wole Soyinka, Ibadan: Malthouse Press,p.80.Henceforth cited as PWS.

11. For details see Zia Jaffrey "An Encounter With Kongi",New York Times, May 1,1997 as published in Tell, a prominent Nigerian Newsmagazine No 28,July 14,1997.Henceforth cited as ZJ

12.Wole Soyinka 'Culture, Memory and Development' in Ismail Serageldin and June Taboroff (eds.),Proceedings of an International Conference held at The World bank, Washington D.C, April 2 and 3,1992,published under the Environmentally Sustainable Development Proceedings Series,No.1,p.201.Henceforth Cited as CMD.

13. Reference is to on Wole Soyinka's novel entitled The Interpreters.

14. Reference is to on Wole Soyinka's non-fictional work entitled Interventions. The work is published in series.

15. A.Bamikunle,1991, Introduction to Soyinka's Poetry Analysis of A Shuttle in the Crypt, Zaria: Ahmadu Bello University Press.

16. Following the birth of Pyrates Confraternity, about 87 more organizations came into existence in Nigerian higher institutions claiming some vision and mission for the society. The result is that a series of violent clashes and sporadic shootings aimed at harming or maiming others has become a regular feature of campus life in Nigerian universities and higher institutions. For details see Education Today,Vol.10,No.2,December 2003,p.9 and K.Babarinde and 
O.A.Adesoji "Effects of Student's Cults in Nigerian Educational System", African Insight,Vol.35,No.1,April 2005,p.44-51.It is in the light of the continued danger of these organizations to peace and security in Nigerian higher educational institutions that it is now strongly held that the vision that informed the birth of Pyrates Confraternity is a wrong one.

17. Wumi Raji, "Review of Understanding of Bretch and Soyinka" by Edde M.Iji published under the title "The New Morality". For details see Kwanascope Journal of Association of Nigerian Authors Kwara State Chapter,Vol.1,No.1,Nov.1993,p.23.Henceforth cited as UBS. 18. Reference is to the Wole Soyinka's play entitled Strong Breed.

19. Nduka Otiono "Kongi's Gunfire for the Season “,Preface Interview with Wole Soyinka, published in to Classique Magazine, Dec 28,1992,p.47.Henceforth cited as KGS.

20. Samuel Enoch Stumpf, 1989, Philosophy: History and Problems, (New York: MCgraw-Hill Book company),p.392.Henceforth cited as PHP

21. Robert C.Solomon, 2003, Living With Nietzschei (Oxford University Press),p.194,Henceforth cited as LWN

22. Peter Poellner, 1995,Nietzsche and Metaphysics (New York :Oxford University Press),202.

23. A Dance of the Forest: Wole Soyinka's play which was staged to mark the Nigeria' independence from Britain in 1960.

24. The Road is a title of Wole Soyinka's play.

25. The Interpreters is a title of Wole Soyinka's novel.

26. Idanre is a title of Wole Soyinka's collection of poems

27. Quote is taken from Fredrick Nietzsche, Beyond Good and Evil as cited in LWN, op.cit, p.192.

28. Lee Spinks, 2003, (London: Routeledge),

p.116.Hencefroth cited as FN 
30. For details of African Philosophy of Communalism on which this position is anchored, see Chukwuemeka Nze, 1989, Aspects of African Communalism (Onitsha : Veritas Publishers.

*Dr. Lawrence Ogbo Ugwuanyi is of the Department of Philosophy, University of Abuja, Abuja. 